\title{
Effect of dietary energy source and level on nutrient digestibility, rumen microbial protein synthesis, and milk performance in lactating dairy cows
}

\author{
X. Q. Zhou, ${ }^{*} \dagger^{1}$ Y. D. Zhang, $\dagger^{1}$ M. Zhao, $†$ T. Zhang, $†$ D. Zhu, D. P. Bu, $\dagger \ddagger \S^{2,3}$ and J. Q. Wang ${ }^{*} \dagger^{2,3}$ \\ ${ }^{*}$ College of Animal Science and Technology, Northeast Agricultural University; Harbin 150030, P. R. China \\ †State Key Laboratory of Animal Nutrition, Institute of Animal Science, Chinese Academy of Agricultural Sciences, Beijing, 100193, P. R. China \\ $\ddagger$ Synergetic Innovation Center of Food Safety and Nutrition, Harbin, 150030, P. R. China \\ $\S$ Chinese Academy of Agricultural Sciences-International Center for Research in Agroforestry, Joint Laboratory on Agroforestry and Sustainable \\ Animal Husbandry, World Agroforestry Centre, East and Central Asia, Beijing 100193, P. R. China
}

\section{ABSTRACT}

This study was conducted to examine the effects of dietary energy source and level on intake, digestion, rumen microbial protein synthesis, and milk production in lactating dairy cows, using corn stover as a forage source. Eight multiparous Holstein cows, 4 of which were fitted with rumen cannulas, were evaluated in a replicated $4 \times 4$ Latin square design, with each period lasting $21 \mathrm{~d}$. The cows were randomly assigned into 4 treatment groups: low-energy (LE) ground corn (GC), LE steam-flaked corn (SFC), high-energy (HE) GC, and HE SFC. Changes to ruminal energy degradation rates were induced by feeding the cows diets of either finely ground corn or SFC as components of diets with the same total energy level. Milk yield, milk protein content and yield, and milk lactose yield all increased in response to higher levels of dietary energy, whereas contents of milk fat and lactose were unaffected. Cows fed HE diets had a higher crude microbial protein yield and total-tract apparent digestibility than those receiving LE diets. Milk yield, milk protein yield, and microbial protein yield were also higher when SFC replaced $\mathrm{GC}$ as the main energy source for lactating cows fed LE diets. These results suggest that an increased dietary energy level and ruminal degradation rate are beneficial to milk protein production, which we suggest is due to increased yields of microbial proteins, when cows are fed corn stover as a dietary forage source.

Key words: energy, corn stover, microbial protein, nutrient digestibility, lactation performance

Received January 5, 2015

Accepted June 19, 2015.

${ }^{1}$ These authors contributed equally to the study.

${ }^{2}$ Corresponding authors: budengpan@126.com and wang-jia-qi@263. net

${ }^{3}$ Current address: State Key Laboratory of Animal Nutrition, Institute of Animal Science, Chinese Academy of Agricultural Sciences, No. 2 Yuanmingyuan West Road, Haidian District, Beijing, 100193, P. R. China.

\section{INTRODUCTION}

Efficient milk production and high quality milk composition are both of great economic importance to dairy farmers. Lactation performance can be effectively improved by managing cow diets and enhancing the conversion of feed into milk (Brun-Lafleur et al., 2010), and it is well documented that high dietary energy input and protein supplementation are critical for effective lactation (Wang et al., 2014). In China, corn stover (CS) is the primary forage material used on small dairy farms (Zhao and Li, 2009; Zhu et al., 2013); however, CS contains low levels of $\mathrm{CP}, \mathrm{NFC}$, and readily fermentable carbohydrates. Corn stover is therefore an inadequate source of the energy necessary to synthesize microbial crude protein (MCP), and reliance solely on CS feeding often leads to decreased milk production (Cooke et al., 2008; Zhao and Li, 2009). Indeed, it has been concluded that feed with an adequate energy content for MCP synthesis is critical for lactation in dairy cows fed low-quality forage such as CS (Zhu et al., 2013).

Ground corn (GC) is an excellent source of energy due to its high content of readily fermentable carbohydrates (i.e., starch). However, the different methods that are used for corn processing can change ruminal starch availability (Theurer et al., 1999). When compared with intact corn grains, steam-flaked corn (SFC) is more readily digestible due to changes in the structure of the starch granules following exposure to a combination of moisture, heat, and pressure. As a result, the use of SFC improves starch utilization and increases the energy available for MCP synthesis (Theurer et al., 1999). Additionally, the combination of corn grain and forage in a cow's diet can make an important contribution to total energy and protein availability. Differences in energy metabolism, and hence ruminal carbohydrate fermentation and milk production, have been observed when the diets of dairy cows consist of processed corn in combination with different forages (Wilkerson et al., 1997; Yu et al., 1998). However, little is known about 
the effects of SFC on lactation performance in cows fed CS as their primary forage. This current study was conducted to evaluate the digestibility of the feed, MCP synthesis and lactation performance of dairy cows fed different amounts of CS in the form of either GC or SFC.

\section{MATERIALS AND METHODS}

The use and care of the animals used in this study were approved by the Animal Care Advisory Committee of the Chinese Academy of Agricultural Sciences. The health of the cows was monitored continuously before and during the experimental period.

\section{Animals and Experimental Design}

Eight primiparous Chinese Holstein cows (138 \pm 19.4 DIM, $29 \pm 0.8 \mathrm{~kg} / \mathrm{d}$ milk, and $589 \pm 57.6 \mathrm{~kg}$ of BW), 4 of which were fitted with ruminal cannula, were used in a replicated $4 \times 4$ Latin square design, with a $2 \times 2$ factorial arrangement of treatments [energy level: $\mathrm{NE}_{\mathrm{L}}$ 1.52-1.53 Mcal for low energy (LE) and 1.71-1.72 Mcal for high energy (HE); energy source: SFC and GC]. The Latin square was balanced for carryover effects. Each experimental period consisted of $14 \mathrm{~d}$ for adaptation and $7 \mathrm{~d}$ for sample collection. The cows were housed in a free-stall barn using a computerized monitoring system (RIC system, Insentec B.V., Marknesse, the Netherlands). The system automatically identified individual cows by ear tags and recorded their feeding behaviors, including time and duration, as well as the quantity of feed intake at each meal.

The experimental diets (Tables 1 and 2) were formulated to meet the nutrient demand of energy, protein content, minerals, and vitamins according to the Feeding Standards of Dairy Cattle (Ministry of Agriculture of P. R. China, 2004). The treatments included 2 forages (36\% CS or $13 \%$ CS plus $22 \%$ corn silage) and 2 forms of corn (Table 3): GC (mean particle size: 1,030 $\mu \mathrm{m})$ and SFC (density: $360 \mathrm{~g} / \mathrm{L}$ ). The experimental diets were provided twice daily $(0630,1630 \mathrm{~h}$ ) for ad libitum intake, allowing for $5 \%$ orts, with free access to water. Cows were milked 3 times daily, at 0700, 1330, and $2030 \mathrm{~h}$.

\section{Sample Collection and Analysis}

Milk production was recorded and milk samples were collected on d 15, 16, and 17 of each experimental period. Two 50-mL aliquots of milk were collected during each milking, and these were pooled in a proportion of 4:3:3 (Zhu et al., 2013; Wang et al., 2014). To one subsample, Bronopol (milk preservative, D\&F Control
Table 1. Composition of the 4 experimental diets with different dietary energy level and grain processing method $^{1}$

\begin{tabular}{|c|c|c|c|c|}
\hline \multirow[b]{2}{*}{ Item } & \multicolumn{2}{|c|}{$\mathrm{LE}$} & \multicolumn{2}{|c|}{$\mathrm{HE}$} \\
\hline & $\mathrm{GC}$ & SFC & $\mathrm{GC}$ & $\mathrm{SFC}$ \\
\hline Corn silage & 0 & 0 & 22 & 22 \\
\hline Corn stover & 35.6 & 35.6 & 13 & 13 \\
\hline Soybean meal & 11.29 & 11.29 & 11.29 & 11.29 \\
\hline Rapeseed meal & 6.32 & 6.32 & 6.32 & 6.32 \\
\hline Extruded soybeans & 2.06 & 2.06 & 2.06 & 2.06 \\
\hline Beet pulp & 4.16 & 4.16 & 4.16 & 4.16 \\
\hline Cottonseed meal & 10.44 & 10.44 & 10.44 & 10.44 \\
\hline Ground corn & 25.56 & 0 & 25.56 & 0 \\
\hline Steam-flaked corn & 0 & 25.56 & 0 & 25.56 \\
\hline $\mathrm{EB} 100^{2}$ & 1.24 & 1.24 & 1.84 & 1.84 \\
\hline $\mathrm{XP}^{3}$ & 0.33 & 0.33 & 0.33 & 0.33 \\
\hline Limestone & 0.74 & 0.74 & 0.74 & 0.74 \\
\hline Salt & 0.46 & 0.46 & 0.46 & 0.46 \\
\hline Premix ${ }^{4}$ & 0.53 & 0.53 & 0.53 & 0.53 \\
\hline Sodium bicarbonate & 0.92 & 0.92 & 0.92 & 0.92 \\
\hline Magnesium oxide & 0.35 & 0.35 & 0.35 & 0.35 \\
\hline
\end{tabular}

${ }^{1} \mathrm{LE}=$ low energy TMR; HE = high energy TMR; GC = ground corn; $\mathrm{SFC}=$ steam-flaked corn.

${ }^{2}$ EB100 is mainly a saturated FFA supplement (EnergyBooster 100, Milk Specialties Global, Eden Prairie, MN).

${ }^{3} \mathrm{XP}$ is a yeast culture supplement (Diamond V, Cedar Rapids, IA).

${ }^{4}$ Premix contained (DM basis) $99.07 \%$ of ash, $14.27 \%$ of Ca, $5.42 \%$ of $\mathrm{P}, 4.96 \%$ of $\mathrm{Mg}, 0.05 \%$ of $\mathrm{K}, 10.67 \%$ of $\mathrm{Na}, 2.98 \%$ of $\mathrm{Cl}, 0.37 \%$ of $\mathrm{S}$, $11 \mathrm{mg} / \mathrm{kg}$ of $\mathrm{Co}, 577 \mathrm{mg} / \mathrm{kg}$ of $\mathrm{Cu}, 4,858 \mathrm{mg} / \mathrm{kg}$ of $\mathrm{Fe}, 51 \mathrm{mg} / \mathrm{kg}$ of I, $1,806 \mathrm{mg} / \mathrm{kg}$ of Mn, $13 \mathrm{mg} / \mathrm{kg}$ of Se, $1,694 \mathrm{mg} / \mathrm{kg}$ of Zn, 115,240 $\mathrm{IU} / \mathrm{kg}$ of vitamin $\mathrm{A}, 46,100 \mathrm{IU} / \mathrm{kg}$ of vitamin $\mathrm{D}$, and $576 \mathrm{IU} / \mathrm{kg}$ of vitamin $\mathrm{E}$.

Systems, San Ramon, CA) was added as a preservative, and this subsample was then stored at $4^{\circ} \mathrm{C}$ for future analysis of protein, fat, lactose, TS, and SCC content by infrared analysis (Laporte and Paquin, 1999) with a Foss-Milkoscan Minor (MilkoScan FT120, Foss Electric

Table 2. Nutrient composition of the 4 experimental diets with different dietary energy level and grain processing method $^{1}$

\begin{tabular}{|c|c|c|c|c|}
\hline \multirow[b]{2}{*}{ Item } & \multicolumn{2}{|c|}{ LE } & \multicolumn{2}{|c|}{$\mathrm{HE}$} \\
\hline & GC & $\mathrm{SFC}$ & $\mathrm{GC}$ & $\mathrm{SFC}$ \\
\hline DM, $\%$ & 42.1 & 42.8 & 44.9 & 44.9 \\
\hline $\mathrm{OM}, \%$ of $\mathrm{DM}$ & 92.9 & 93.0 & 93.5 & 93.8 \\
\hline Ash, $\%$ of DM & 7.07 & 7.05 & 6.49 & 6.16 \\
\hline $\mathrm{CP}, \%$ of $\mathrm{DM}$ & 16.5 & 16.5 & 16.8 & 16.1 \\
\hline Ether extract, \% of DM & 2.58 & 2.78 & 3.92 & 3.95 \\
\hline $\mathrm{NDF}, \%$ of DM & 43.8 & 43.0 & 36.2 & 36.7 \\
\hline $\mathrm{ADF}, \%$ of $\mathrm{DM}$ & 35.4 & 36.9 & 31.4 & 31.3 \\
\hline $\mathrm{NFC}^{2} \%$ of $\mathrm{DM}$ & 30.0 & 30.7 & 36.6 & 37.1 \\
\hline Starch, \% of DM & 22.3 & 22.8 & 24.4 & 24.9 \\
\hline $\mathrm{Ca}, \%$ of $\mathrm{DM}$ & 0.64 & 0.64 & 0.57 & 0.57 \\
\hline Total P, $\%$ of DM & 0.36 & 0.44 & 0.45 & 0.45 \\
\hline $\mathrm{NE}_{\mathrm{L}},{ }^{3} \mathrm{Mcal} / \mathrm{kg}$ of DM & 1.52 & 1.53 & 1.71 & 1.72 \\
\hline
\end{tabular}

${ }^{1} \mathrm{LE}=$ low energy TMR; HE = high energy TMR; GC = ground corn; $\mathrm{SFC}=$ steam-flaked corn .

${ }^{2}$ Calculated as $100-(\% \mathrm{NDF}+\% \mathrm{CP}+\%$ ether extract $+\%$ ash $)$.

${ }^{3}$ Calculated based on Feeding Standards of Dairy Cattle (Ministry of Agriculture of P. R. China recommendations, 2004). 
Table 3. Nutrient composition (mean $\pm \mathrm{SD}$ ) of forage and corn grain components used in the experimental diets $(\mathrm{n}=8)$

\begin{tabular}{|c|c|c|c|c|}
\hline Item & Corn stover & Corn silage & Ground corn & Steam-flaked corn \\
\hline $\mathrm{CP}, \%$ of $\mathrm{DM}$ & $6.93 \pm 0.44$ & $9.05 \pm 0.21$ & $9.24 \pm 0.43$ & $8.33 \pm 0.39$ \\
\hline Ash, $\%$ of DM & $9.95 \pm 0.43$ & $6.89 \pm 0.13$ & $1.49 \pm 0.12$ & $0.93 \pm 0.12$ \\
\hline $\mathrm{ADF}, \%$ of $\mathrm{DM}$ & $41.8 \pm 3.87$ & $26.7 \pm 1.32$ & $2.88 \pm 0.21$ & $2.46 \pm 0.14$ \\
\hline Ether extract, $\%$ of DM & $2.37 \pm 0.02$ & $3.21 \pm 0.02$ & $2.96 \pm 0.51$ & $2.28 \pm 0.32$ \\
\hline $\mathrm{NFC},{ }^{1} \%$ of DM & $16.1 \pm 0.99$ & $35.0 \pm 1.78$ & $78.3 \pm 2.02$ & $81.1 \pm 2.33$ \\
\hline Starch, \% of DM & $2.74 \pm 0.17$ & $29.67 \pm 0.83$ & $73.3 \pm 2.11$ & $72.7 \pm 2.44$ \\
\hline
\end{tabular}

${ }^{1}$ Calculated as $100-(\% \mathrm{NDF}+\% \mathrm{CP}+\%$ ether extract $+\%$ ash $)$.

A/S, Hillerød, Denmark). Proven accuracy based on renowned FOSS technology MilkoScan Minor is based on the well-known mid-infrared measuring principle.

The weight of the feed offered and refused was measured to determine DMI during the final $7 \mathrm{~d}$ of each period. Ration and ort samples were collected every week to assess the DM content of the consumed and refused feed. Feed samples were dried at $65^{\circ} \mathrm{C}$ for $48 \mathrm{~h}$ (Mechanical Convection Oven, Freas 645, Thermo Electron Corp., Waltham, MA, Cheng et al., 2014), then ground through a 1-mm mesh screen using a Wiley mill (Arthur H. Thomas Co., Philadelphia, PA) for subsequent analyses of $\mathrm{DM}\left(105^{\circ} \mathrm{C}\right.$ for $\left.5 \mathrm{~h}\right)$, CP (method 988.05; AOAC, 1990), ash (method 942.05; AOAC, 1990), and ADF (method 973.18; AOAC, 1990). The NDF content was determined using the Ankom A200 fiber analyzer (Ankom Technology, Macedon, NY), and previously reported methods (Van Soest et al., 1991), with $\alpha$-amylase and sodium sulfide. Starch content was determined using a colorimetric method (Weiss and Wyatt, 2000).

Fecal samples (approximately $100 \mathrm{~g}$, wet weight) were collected from the rectum of each cow every $6 \mathrm{~h}$ on d 19, 20, and 21 of each experimental period, resulting in 12 representative fecal samples per cow. Samples from each time point were divided into 2 portions and samples were pooled across sampling times for each cow. A $10 \%$ volume of $6 \mathrm{M}$ hydrochloric acid was added to one pooled portion from each cow immediately after sampling for subsequent nitrogen analysis. All fecal samples were dried at $65^{\circ} \mathrm{C}$ for $48 \mathrm{~h}$, ground using a Wiley mill (Arthur H. Thomas Co.) and passed through a 1-mm mesh screen. During each 3-d collection period, TMR and ort samples were collected daily and stored at $-20^{\circ} \mathrm{C}$ for subsequent analysis. Apparent total-tract nutrient digestibility was calculated using indigestible NDF (iNDF) as an internal marker based on the concentration of iNDF in the diet and feces, where iNDF (12-d ruminal incubation in 25- $\mu \mathrm{m}$-pore-size bags) was determined as described by Lee and Hristov (2013).

\section{In Situ Degradation}

Three ruminally cannulated Holstein cows (575 \pm $24.9 \mathrm{~kg}$ of BW, $26.9 \pm 1.43 \mathrm{~kg}$ of milk yield, and $271 \pm$ $89.7 \mathrm{~d}$ in milk) were housed to determine the DM and $\mathrm{CP}$ degradation of the 4 provided diets. The basal diet (\% of DM) consisted of $21.2 \%$ corn silage, $20.4 \%$ alfalfa, and $58.4 \%$ concentrate mixture and was supplied 3 times daily at 0700,1400 , and $2000 \mathrm{~h}$ for a total DMI of $1.5 \%$ of BW. The TMR samples for the degradation study were dried at $65^{\circ} \mathrm{C}$, ground using a Wiley mill (Arthur H. Thomas Co.), and passed through a 3-mm screen. Approximately $5 \mathrm{~g}$ of DM from each sample was weighed places in nylon bags $(10 \times 20 \mathrm{~cm} ; 50 \mu \mathrm{m}$ pore size; Ankom Technology Corp.), which were then tied to the end of a $40-\mathrm{cm}$ nylon line. The nylon bags were placed in the ventral sac of the rumen through the ruminal cannulas and incubated for 2, 4, 8, 12, 16, 24, 36, or $48 \mathrm{~h}$. After removal from the rumens, the bags were rinsed thoroughly in cool running tap water until the wash water was clear. The samples were then dried in an oven at $65^{\circ} \mathrm{C}$ for $48 \mathrm{~h}$ and weighed to determine the residue masses. The residues and original TMR samples were then ground to pass through a $1-\mathrm{mm}$ screen in a Cyclotec mill (Tecator 1093, Tecator AB, Hoganäs, Sweden) for DM and CP analysis. The constants of the in situ degradation were estimated using the nonlinear model described by Ørskov et al. (1980): $P=a+b$ $[1-\exp (-c t)]$, where $P=$ the rate of disappearance at time $t(\mathrm{~h}), a=$ the soluble fraction, and $b=$ the slowly degraded fraction, which degrades at rate $c(c$ $>0)$. The effective degradability ( $\mathrm{dg}$ ) was calculated assuming a passage rate $(k p)$ of $4.6 \% / \mathrm{h}$ (Krizsan et al., 2010): $d g=a+b c /(c+k p)$, where $a, b, c$, and $k p$ are the constants described above.

\section{Estimation of MCP}

The MCP yield was calculated from urinary purine derivative excretion (PD), based on the relationship 
derived by Chen and Gomes (1992). Spot urine samples (each about $200 \mathrm{~g}$ ) were collected 4 times daily at approximately $0100,0700,1300$, and $1900 \mathrm{~h}$ on d 19;0300, 0900, 1500, and $2100 \mathrm{~h}$ on d 20; and 0500, 1100, 1700, and $2300 \mathrm{~h}$ on $\mathrm{d} 21$ of each period. Urine samples from each cow were pooled and a $10 \mathrm{~mL}$ of each subsample was acidified with $40 \mathrm{~mL}$ of $0.036 \mathrm{~mol}$ of $\mathrm{H}_{2} \mathrm{SO}_{4} / \mathrm{L}$ and immediately stored at $-20^{\circ} \mathrm{C}$ for subsequent analysis (Wang et al., 2014). The PD (allantoin and uric acid) was determined using the procedure described in Chen and Gomes (1992), and creatinine content was calculated using a colorimetric picric acid assay (Oser, 1965). Creatinine is an established marker for determining urine volume (Leonardi et al., 2003) and was assumed to be excreted at a rate of $29 \mathrm{mg} / \mathrm{kg}$ of BW to calculate the urine volume excretion rate (Valadares et al., 1999).

The intestinally absorbable dietary protein (IADP) was calculated using the following equation: IADP = RUP $\times$ CP intake $\times$ IDP, where IDP is the intestinal digestibility of RUP, determined from the residue of feedstuff incubated in the rumen for $16 \mathrm{~h}$ using a modified 3-step procedure (Gargallo et al., 2006).

\section{Statistical Analysis}

Feed intake, lactation performance, feed efficiency, urine volume, urinary $\mathrm{PD}$, and apparent digestibility were determined using the PROC MIXED procedure of SAS (SAS Institute Inc., Cary, NC). The following model was used for the analysis as a replicated, $4 \times 4$ Latin square design:

$$
\mathrm{Y}_{\mathrm{jk12}}=\mu+\mathrm{P}_{\mathrm{j}}+\mathrm{C}_{\mathrm{k}}+\mathrm{T}_{1}+\mathrm{T}_{2}+\mathrm{T}_{12}+\mathrm{E}_{\mathrm{jk} 12},
$$

$Y_{j k 12}$ is the dependent variable, $\mu$ is the overall mean, $P_{j}$ is the fixed effect of period $j, C_{k}$ is the random effect of cow $\mathrm{k}, \mathrm{T}_{1}$ is the fixed effect of the source, $\mathrm{T}_{2}$ is the fixed effect of dietary energy level, $\mathrm{T}_{12}$ is the interaction between the dietary energy level and the source of the diet, and $\mathrm{E}_{\mathrm{jk} 12}$ is the residual error. The constants (a, $\mathrm{b}, \mathrm{c}$, and $\mathrm{dg}$ ) of DM and CP degradation, RUP, and intestinal digestion variables were also determined using the MIXED model, where treatment was used as a fixed effect and the individual cow was considered as a random effect. A statistically significant difference was defined at $P \leq 0.05$, and trends were declared at 0.05 $<P \leq 0.10$.

\section{RESULTS AND DISCUSSION}

\section{Production Response}

Dry matter intake and production responses are presented in Table 4. Other than milk fat percentage and SCC, all values associated with milk production and composition were higher for cows fed the HE diet than those fed the LE diet. We also observed that the milk yield/DMI $(P=0.05)$ and $\operatorname{ECM}(P=0.08)$ was greater for cows fed the LE diet than those for fed the HE diet. The DMI increased significantly when cows were fed the HE diet, but this was not observed with the LE diet. High forage NDF content has been shown to reduce diet digestibility and passage rates in the cow rumen, thereby restricting the DMI (Van Soest et al., 1991; Pinos-Rodríguez et al., 2002), as NDF content has been shown to be negatively correlated with DMI (Allen, 2000). The HE diet contained corn silage and a high fat concentrations, thereby increasing the dietary levels of starch and crude fat (ether extract, EE; Table 2 ), as well as rumen fermentable carbohydrates, nonstructural carbohydrates, and available energy for milk production. In the current study, the increase in milk protein and milk yield in cows fed a HE diet was likely due to these changes, which is congruent with earlier studies (Poore et al., 1993; Simas et al., 1997).

No differences in DMI were observed when diets were supplemented with either GC or SFC, which is in general agreement with a previous study comparing these 2 parameters (Dhiman et al., 2002). However, the interaction between dietary energy level and source was significant in terms of DMI $(P<0.01)$. Yields of milk protein $(P<0.01), 4 \%$ FCM $(P<0.01)$, ECM $(P<$ 0.01 ), and milk protein percentage were all greater for cows fed SFC than for those fed GC, with an average milk yield of $23.3 \mathrm{~kg} / \mathrm{d}$ for cows receiving the LE/GC diet and $25.8 \mathrm{~kg} / \mathrm{d}$ for those receiving the LE/SFC diet. Interestingly, we observed no difference in milk protein percentage and yields between cows fed the HE/GC or the HE/SFC diets. At the same time, we noted a significant interaction between energy level and source for ECM $(P<0.01)$ and FCM $(P<0.01)$, which suggested that their effects were not additive. When cows were fed LE diets, the greater DM and OM digestibility of the SFC reflects a greater starch digestibility, suggesting that more energy was provided for MCP synthesis to support of milk production. However, no difference was observed in DMI and milk production between cows provided with GC or SFC when they were fed the HE diets.

Studies to date have not resulted in a consensus regarding the effect of SFC on milk protein. Some researchers (e.g., Chen et al., 1994; Dhiman et al., 2002) have reported increased milk protein yields in cows fed SFC, whereas others (Yu et al., 1998; Harvatine et al., 2002) reported no such change. Here, we found that the average milk fat percentage for cows receiving GC was $4.29 \%$, compared with $4.18 \%$ for those receiving SFC $(P=0.34)$. Previous studies have reported that 
Table 4. Dry matter intake and lactation performance of dairy cows fed the 4 experimental diets with different dietary energy level and grain processing method ${ }^{1}$

\begin{tabular}{|c|c|c|c|c|c|c|c|c|}
\hline \multirow[b]{2}{*}{ Item } & \multicolumn{2}{|c|}{$\mathrm{LE}$} & \multicolumn{2}{|c|}{$\mathrm{HE}$} & \multirow[b]{2}{*}{ SEM } & \multicolumn{3}{|c|}{$P$-value ${ }^{2}$} \\
\hline & $\mathrm{GC}$ & $\mathrm{SFC}$ & $\mathrm{GC}$ & $\mathrm{SFC}$ & & $\mathrm{NE}$ & GP & $\mathrm{NE} \times \mathrm{GP}$ \\
\hline \multicolumn{9}{|l|}{ Production } \\
\hline $4 \% \mathrm{FCM}^{3} \mathrm{~kg} / \mathrm{d}$ & $\begin{aligned} 20.0 \\
238\end{aligned}$ & $\begin{array}{r}25.8 \\
263\end{array}$ & 27.4 & 28.2 & 0.33 & $<0.01$ & 0.13 & 0.06 \\
\hline $4 \%$ FCM, $\mathrm{kg} / \mathrm{d}$ & 23.8 & 26.3 & 29.0 & 29.0 & 0.37 & $<0.01$ & $<0.01$ & 0.01 \\
\hline $\mathrm{ECM}^{4}{ }^{4} \mathrm{~kg} / \mathrm{d}$ & 25.6 & 28.3 & 31.2 & 31.2 & 0.38 & $<0.01$ & $<0.01$ & 0.01 \\
\hline Lactose yield, $\mathrm{kg} / \mathrm{d}$ & 1.15 & 1.25 & 1.33 & 1.35 & 0.02 & $<0.01$ & 0.04 & 0.22 \\
\hline \multicolumn{9}{|l|}{ Composition } \\
\hline Protein, \% & 3.04 & 3.14 & 3.15 & 3.19 & 0.03 & 0.01 & $<0.01$ & 0.55 \\
\hline Fat, $\%$ & 4.26 & 4.23 & 4.31 & 4.12 & 0.07 & 0.51 & 0.34 & 0.43 \\
\hline Lactose, \% & 4.90 & 4.89 & 4.93 & 4.95 & 0.01 & $<0.01$ & 0.70 & 0.40 \\
\hline Total solids, \% & 13.3 & 13.2 & 13.3 & 13.0 & 0.11 & 0.20 & 0.78 & 0.93 \\
\hline SNF, $\%$ & 8.76 & 8.81 & 8.88 & 8.93 & 0.04 & $<0.01$ & 0.10 & 0.88 \\
\hline
\end{tabular}

${ }^{1} \mathrm{LE}=$ low energy TMR; HE = high energy TMR; GC = ground corn; SFC = steam-flaked corn.

${ }^{2} \mathrm{NE}=$ main effect of dietary energy level; GP $=$ main effect of grain processing method; $\mathrm{NE} \times \mathrm{GP}=$ interaction of dietary energy level and grain processing method.

${ }^{3} 4 \%$ FCM $(\mathrm{kg} / \mathrm{d})=0.4 \times$ milk $(\mathrm{kg} / \mathrm{d})+15 \times$ fat $(\mathrm{kg} / \mathrm{d})$.

${ }^{4} \operatorname{ECM}(\mathrm{kg} / \mathrm{d})=0.327 \times$ milk $(\mathrm{kg} / \mathrm{d})+12.95 \times$ fat $(\mathrm{kg} / \mathrm{d})+7.65 \times$ protein $(\mathrm{kg} / \mathrm{d})$.

the milk fat percentage was reduced, on average, by $7 \%$ when cows were fed SFC as opposed to finely ground corn (Dhiman et al., 2002), and in a review of the effects of steam-flaking grain it was also noted that diets including SFC resulted in a reduction in milk fat content by 4 to $5 \%$, although milk fat yield was unaltered (Theurer et al., 1999).

Efficiency, defined as kilograms of milk per kilogram of DMI, was greater for cows fed SFC (1.47) as opposed to GC (1.33) as part of LE diets, whereas efficiency of ECM and FCM were similar between corn sources. The increased efficiency for cows fed SFC was due to greater milk yields and lower DMI. In contrast, ECM and FCM efficiencies were higher for cows fed GC as opposed to SFC as part of an $\mathrm{HE}$ diet, reflecting the higher milk fat content and milk fat yield of $\mathrm{HE} / \mathrm{GC}$ compared with $\mathrm{HE} / \mathrm{SFC}$.

\section{Rumen Degradation and Estimated MCP Yield}

In Situ Rumen Degradation. The results for rumen degradation of $\mathrm{CP}$ and $\mathrm{DM}$ are presented in Table 5. No differences in rumen degradation of $\mathrm{CP}$ and DM were observed when diets were supplemented with either GC or SFC. The DM degradation at $48 \mathrm{~h}$ was higher $(P=0.03)$ for cows fed the HE diet than the LE diet. For the CP degradation, LE diet contained lower $(P=0.04)$ slowly degraded fraction ( $b$ value) and lower $(P=0.02)$ rate of the slowly degraded fraction ( $c$ value) of $\mathrm{CP}$ than did the HE diet. The soluble fraction ( $a$ value), effective degradability ( $d g$ value) of $\mathrm{CP}$ degradation and RUP did not differ among the 4 diets.

Intestinal Digestibility of RUP and Estimated $\boldsymbol{M C P}$. The IDP, IADP, urinary PD, and estimated MCP values are shown in Table 6 . No differences $(P$ $>0.05)$ were found in IDP values between the dietary treatments, and whereas IADP was higher for cows fed the HE diets than the LE diets $(P<0.01)$, no such difference $(P=0.21)$ was present between those fed GC or SFC diets. The sum of urinary PD was also higher $(P<0.01)$ for cows fed the HE diets than it was for those fed the LE diets, and also higher $(P<0.01)$ for SFC diets than it was for GC diets. Thus, the estimated MCP yield was shown to be higher for the HE diets.

Milk protein secretion in dairy cows is closely associated with their dietary supply of $\mathrm{CP}$, rumen fermentable carbohydrates, and MP (NRC, 2001; Zhu et al., 2013; Wang et al., 2014), whereas energy supply also plays an important role in MCP and MP synthesis. In the present study, both MCP and IADP values were higher in cows fed HE diets, which we propose are associated with greater MP supply and milk protein yield. Previous research has shown that a greater concentration of dietary NFC is positively correlated with MCP 
Table 5. Crude protein degradation constants based on the equation $P=a+b[1-\exp (-c t)]$, where $P=$ the rate of disappearance at time $\mathrm{t}(\mathrm{h}), a=$ the soluble fraction in the rumen, and $b=$ the fraction slowly degraded at rate $c(c>0)$; their effective degradability (dg); DM degradation at $48 \mathrm{~h}$ and RUP of the 4 experimental diets with different dietary energy level and grain processing $\operatorname{method}^{1}$

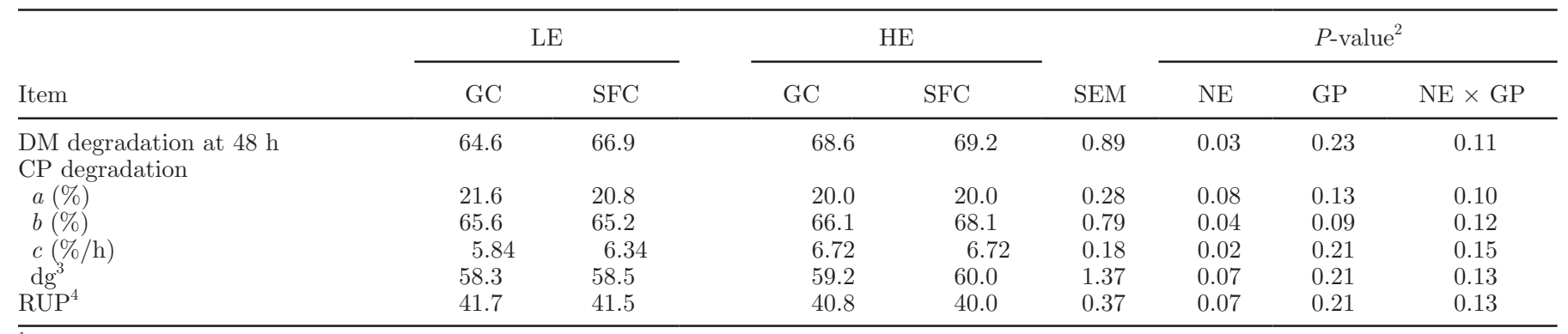

${ }^{1} \mathrm{LE}=$ low energy TMR; HE = high energy TMR; GC = ground corn; SFC = steam-flaked corn.

${ }^{2} \mathrm{NE}=$ main effect of dietary energy level; GP = main effect of grain processing method; $\mathrm{NE} \times \mathrm{GP}=$ interaction of dietary energy level and grain processing method.

${ }^{3} \mathrm{dg}=\mathrm{a}+\mathrm{bc} /(\mathrm{c}+\mathrm{kp})$ (Ørskov et al., 1980), assuming a passage rate (kp) of 4.6\%/h (Madsen and Hvelplund, 1985). Dg = degradability.

${ }^{4} \mathrm{RUP}=100-\mathrm{RDP}$.

yield (Nocek and Russell, 1988; Lascano and Heinrichs, 2011; Wang et al., 2014). In the HE diets, in contrast to the LE diets, CS was replaced with corn silage, thereby increasing the dietary energy level and improving DMI. Consequently, dietary $\mathrm{CP}$ and both $\mathrm{OM}$ intake and degradability increased, providing more rumen fermentable carbohydrates and energy for synthesizing MCP in the rumen (Moscardini et al., 1998; Khorasani et al., 2001; Voelker Linton and Allen, 2009). The cows fed SFC in place of GC in the LE diets also exhibited increased MCP yields, even though the DMI of the LE/ SFC diet was lower than the LE/GC diet. It is possible that the higher DM, OM, and CP digestibility of LE/ SFC improved readily fermentable carbohydrate ingestion in the rumen and that this led to more efficient MCP production.

\section{Nutrient Intake and Digestibility}

Nutrient intake and apparent total-tract digestibility, measured during d 19 to 21 of each period, are presented in Table 7 . Intakes of DM $(P<0.01)$, OM $(P<0.01) \mathrm{CP}(P<0.01)$, and $\operatorname{starch}(P<0.01)$ were greater for cows fed the HE diet than for those fed the

Table 6. Urinary purine derivatives (PD) and estimated MCP supply to dairy cows fed 4 experimental diets with different dietary energy level and grain processing method ${ }^{1}$

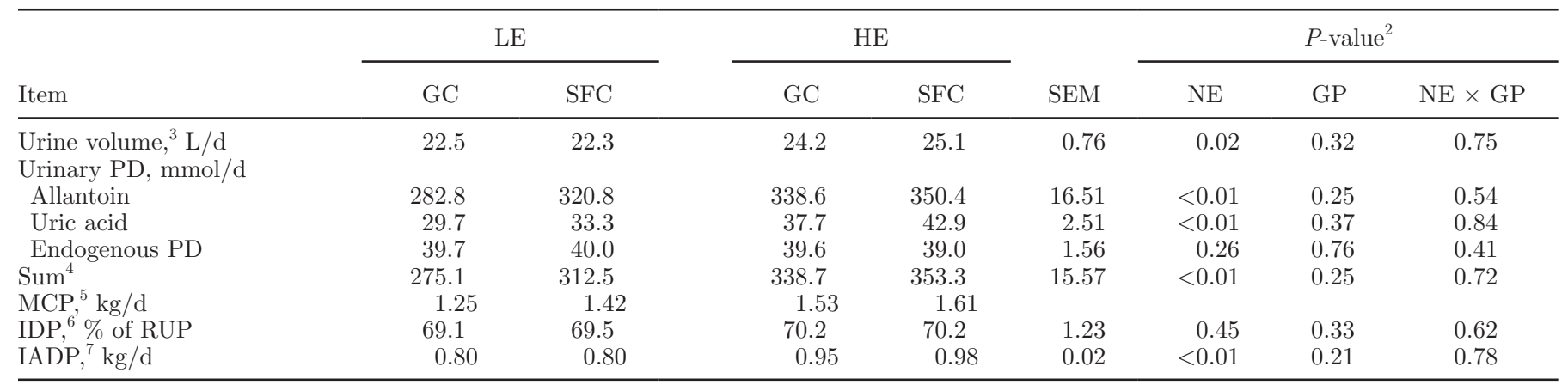

${ }^{1} \mathrm{LE}=$ low energy TMR; HE = high energy TMR; GC = ground corn; SFC = steam-flaked corn.

${ }^{2} \mathrm{NE}=$ main effect of dietary energy level; GP = main effect of grain processing method; $\mathrm{NE} \times \mathrm{GP}=$ interaction of dietary energy level and grain processing method.

${ }^{3}$ Urine volume $(\mathrm{L} / \mathrm{d})=\mathrm{BW}(\mathrm{kg}) \times 29(\mathrm{mg} / \mathrm{d}) /$ creatinine $(\mathrm{mg} / \mathrm{L})$ (Valadares et al., 1999).

${ }^{4} \mathrm{Sum}=$ allantoin + uric acid - endogenous PD.

${ }^{5}$ Microbial CP (MCP) was indirectly estimated by the equation (Chen and Gomes, 1992) MCP $=($ allantoin + uric acid - endogenous PD) $\times$ $70 \times 6.25 /(0.116 \times 0.83 \times 1,000)$.

${ }^{6} \mathrm{IDP}=$ measured intestinal digestibility of RUP. The feedstuff incubated in the rumen for $16 \mathrm{~h}$ was used to determine the IDP according to a modified 3-step procedure (Gargallo et al., 2006).

${ }^{7}$ Intestinally absorbable dietary protein $(\mathrm{IADP})=\mathrm{RUP} \times \mathrm{CP}$ intake $\times$ IDP. 
LE diet, as corn silage replaced CS. Previous studies have examined the effects of replacing alfalfa or Chinese wild rye with CS in dairy cows, and found no difference in DMI (Zhu et al., 2013). Another report indicated that feed intake was not affected by diet but that it was affected by week when cows were fed CS as a forage source rather than alfalfa or rice stover (Wang et al., 2014). However, only a few studies have examined the effects of substituting CS for corn silage in lactating dairy cows. Compared with CS, corn silage contains larger amounts of CP, RDP, RUP, and NFC, but smaller amounts of ADF and NDF (Table 3). We found here that nutrient intake was not affected by the corn source (GC or SFC) in the cows fed the HE diets, which is consistent with a previous report ( $\mathrm{Yu}$ et al., 1998). An increase in digestibility of DM and OM when diets are supplemented with SFC rather than GC has also been reported (Cooke et al., 2009), as has the fact that feed intake was reduced with lowered digestibility of DM (Faverdin et al., 1999). Moreover, with a diet high in digestible energy, the energy intake ceased to increase with ration digestibility (Conrad et al., 1964; Wang et al., 2014). In the current study, HE diets increased the total-tract digestibility of DM, OM, CP, $\mathrm{NDF}, \mathrm{ADF}$, and starch, but no such differences were observed between the HE/GC- and HE/SFC-based diets. Previous studies (Yu et al., 1998; Bernard et al., 2004) did not detect any differences in DM and OM digestibility when diets were supplemented with SFC instead of GC. However, DM, OM, CP, EE, and starch digestibility was greater for LE/SFC diets than it was for LE/GC diets, which contrasts with previous reports (Cooke et al., 2008; Zhong et al., 2008), where the opposite patterns were seen.

In summary, this current study demonstrated that an HE diet with a decrease in the proportion of CS and an increase in the concentration of EB 100, lead to higher intakes and digestibility of DM, CP, EE, and starch. These changes contributed to an increased supply of MCP, RUP, MP, and energy for lactation and improved yields of milk and milk protein compared with LE diets. Additionally, some interactions between dietary energy levels and the energy source were seen to affect lactation performance and DMI. We note that these associations may depend on whether the dietary energy supply met the needs for the cows $(29 \mathrm{~kg} / \mathrm{d}$ milk production). The HE diets, which contained a higher dietary energy level, resulted in greater nutrient intake and digestibility, and provided cows with adequate energy for milk production. This indicates that the greater starch degradation associated with SFC did not play a major role in the energy supply. Our data suggest no difference in milk production resulting from $\mathrm{HE} / \mathrm{GC}$ and $\mathrm{HE} / \mathrm{SFC}$ diets, whereas LE diets, with lower dietary energy level and DMI, did not result in satisfactory lactation. The LE/ SFC diets contained a large amount of easily fermentable carbohydrates and starch, which, along with its rapid DM and OM degradation, were essential for MCP synthesis, although no difference was found in DMI between the LE/GC and LE/SFC diets. Thus, both the milk production and protein production were higher in cows fed the LE/SFC diet than the LE/GC diet.

Table 7. Nutrient intake and total-tract apparent digestibility in dairy cows fed 4 experimental diets with different dietary energy level and grain processing method $^{1}$

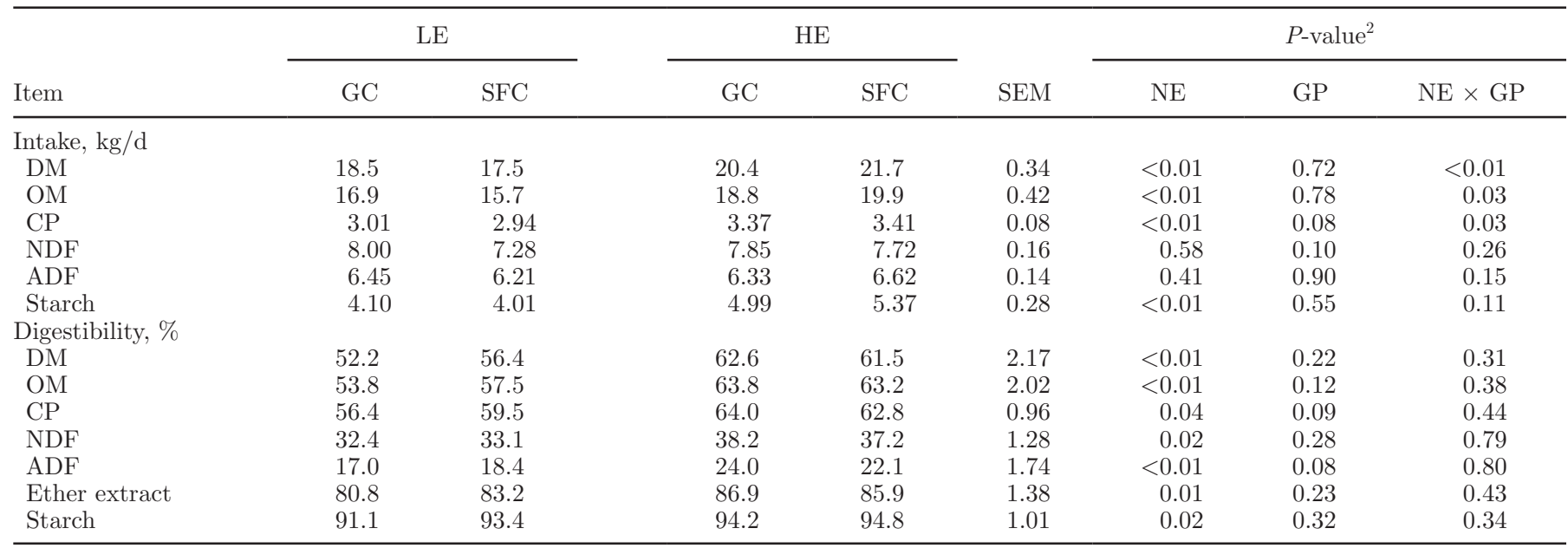

${ }^{1} \mathrm{LE}=$ low energy TMR; HE = high energy TMR; GC = ground corn; SFC = steam-flaked corn.

${ }^{2} \mathrm{NE}=$ main effect of dietary energy level; GP = main effect of grain processing method; $\mathrm{NE} \times \mathrm{GP}=$ interaction of dietary energy level and grain processing method. 


\section{CONCLUSIONS}

The results of the current study indicate that feeding cows a blend of CS and corn silage, and providing more dietary energy, improves lactation performance when compared with feeding the same cows CS as a sole forage source, as the latter contains only low amounts of dietary energy. The increased milk yield of cows fed HE diets in this study can partly be attributed to the greater DMI associated with corn silage. This most likely reflects improved energy absorption from improved total-tract DM digestibility. The diet that included SFC improved performance and efficiency compared with the GC-based diet, and supported greater DM, $\mathrm{CP}, \mathrm{EE}$, and starch digestibility when the cows were fed LE diets. This likely provided additional energy, resulting in improved MCP synthesis and milk production.

\section{ACKNOWLEDGMENTS}

The authors gratefully acknowledge Liam A. Sinclair at Harper Adams University (Newport, UK) and his assistance with editing this paper. We also thank the personnel at Sinofarm Genetics and Seeds Group (Beijing, China) for the feeding, milking, and care of the cows, and Ministry of Agriculture-Milk and Dairy Product Inspection Center (Beijing, China) for assisting in laboratory analyses. This research was partially supported by funds from a National Basic Research Program (973) of China (Beijing; grant no. 2011CB100805), Ministry of Science and Technology of China (Beijing; no. 2012BAD12B02-5; 2012BAD43B01-2), and the Agricultural Science and Technology Innovation Program (Beijing, China; ASTIP-IAS07).

\section{REFERENCES}

Allen, M. S. 2000. Effects of diet on short-term regulation of feed intake by lactating dairy cows. J. Dairy Sci. 83:1598-1624.

AOAC (Association of Official Analytical Chemists). 1990. Official Methods of Analysis. 15th ed. AOAC, Arlington, VA.

Bernard, J. K., P. T. Chandler, J. W. West, A. H. Parks, H. A. Amos, M. A. Froetschel, and D. S. Trammell. 2004. Effect of supplemental L-lysine- $\mathrm{HCl}$ and corn source on rumen fermentation and amino acid flow to the small intestine. J. Dairy Sci. 87:399-405.

Brun-Lafleur, L., L. Delaby, F. Husson, and P. Faverdin. 2010. Predicting energy $\times$ protein interaction on milk yield and milk composition in dairy cows. J. Dairy Sci. 93:4128-4143.

Chen, K. H., J. T. Huber, C. B. Theurer, R. S. Swingle, J. Simas, S. C. Chan, Z. Wu, and J. L. Sullivan. 1994. Effect of steam flaking of corn and sorghum grains on performance of lactating cows. J. Dairy Sci. 77:1038-1043.

Chen, X. B., and M. J. Gomes. 1992. Estimation of microbial protein supply to sheep and cattle based on urinary excretion of purine derivatives: An overview of technical details. Int. Feed Res. Unit, Occasional Publ. Rowett Research Institute, Aberdeen, UK.

Cheng, J. B., D. B. Bu, J. Q. Wang, X. Z. Sun, L. Pan, L. Y. Zhou, and W. Liu. 2014. Effects of rumen-protected $\gamma$-aminobutyric acid on performance and nutrient digestibility in heat-stressed dairy cows. J. Dairy Sci. 97:5599-5607.
Conrad, H. R., A. D. Pratt, and J. W. Hibbs. 1964. Regulation of food intake in dairy cows. 1. Change in importance of physical and physiological factors with increasing digestibility. J. Dairy Sci. $47: 54-62$.

Cooke, K. M., J. K. Bernard, and J. W. West. 2008. Performance of dairy cows fed annual ryegrass silage and corn silage with steamflaked or ground corn. J. Dairy Sci. 91:2417-2422.

Cooke, K. M., J. K. Bernard, and J. W. West. 2009. Performance of lactating dairy cows fed ryegrass silage and corn silage with ground corn, steam-flaked corn, or hominy feed. J. Dairy Sci. 92:1117-1123.

Dhiman, T. R., M. S. Zaman, I. S. Macqueen, and R. L. Boman. 2002. Influence of corn processing and frequency of feeding on cow performance. J. Dairy Sci. 85:217-226.

Faverdin, P., N. Bareille, and R. Verite. 1999. Effects of rumen energy supply timing on feed intake control in lactating dairy cows. J. Dairy Sci. 82:2443-2454.

Gargallo, S., S. Calsamiglia, and A. Ferret. 2006. Technical note: A modified three-step in vitro procedure to determine intestinal digestion of proteins. J. Anim. Sci. 84:2163-2167.

Harvatine, D. I., J. L. Firkins, and M. L. Eastridge. 2002. Whole linted cottonseed as a forage substitute fed with ground or steam-flaked corn: digestibility and performance. J. Dairy Sci. 85:1976-1987.

Khorasani, G. R., E. K. Okine, and J. J. Kennelly. 2001. Effects of forage source and amount of concentrate on rumen and intestinal digestion of nutrients in late-lactation cows. J. Dairy Sci. $84: 1156-1165$

Krizsan, S. J., S. Ahvenjärvi, and P. Huhtanen. 2010. A meta-analysis of passage rate estimated by rumen evacuation with cattle and evaluation of passage rate prediction models. J. Dairy Sci. 93:5890-5901.

Laporte, M. F., and P. Paquin. 1999. Near-infrared analysis of fat, protein, and casein in cow's milk. J. Agric. Food Chem. 47:26002605.

Lascano, G. J., and A. J. Heinrichs. 2011. Effects of feeding different levels of dietary fiber through the addition of corn stover on nutrient utilization of dairy heifers precision-fed high and low concentrate diets. J. Dairy Sci. 94:3025-3036.

Lee, C., and A. N. Hristov. 2013. Short communication: Evaluation of acid-insoluble ash and indigestible neutral detergent fiber as total-tract digestibility markers in dairy cows fed corn silage-based diets. J. Dairy Sci. 96:5295-5299.

Leonardi, C., M. Stevenson, and L. E. Armentano. 2003. Effect of two levels of crude protein and methionine supplementation on performance of dairy cows. J. Dairy Sci. 86:4033-4042.

Madsen, J., and T. Hvelplund. 1985. Protein degradation in the rumen. A comparison between in vivo, nylon bag, in vitro and buffer measurements. Acta Agric. Scand. 25(Suppl.):103.

Ministry of Agriculture of P. R. China (MOA). 2004. Feeding Standard of Dairy Cattle (NY/T 34-2004). MOA, Beijing, China.

Moscardini, S., T. C. Wright, P. H. Luimes, B. W. McBride, and P. Susmel. 1998. Effects of rumen-undegradable protein and feed intake on purine derivative and urea nitrogen: Comparison with predictions from the Cornell Net Carbohydrate and Protein System. J. Dairy Sci. 81:2421-2429.

Nocek, J. E., and J. B. Russell. 1988. Protein and energy as an integrated system: Relationship of ruminal protein and carbohydrate availability to microbial synthesis and milk production. J. Dairy Sci. 71:2070-2107.

NRC. 2001. Nutrient Requirements of Dairy Cattle. 7th rev. ed. Natl. Acad. Sci., Washington, DC.

Ørskov, E. R., F. D. De, B. Hovell, and F. Mould. 1980. The use of the nylon bag technique for the evaluation of feedstuffs. Trop. Anim. Prod. 5:195-213.

Oser, B. L. 1965. Hawk's Physiological Chemistry. 14th ed. McGraw Hill, New York, NY.

Pinos-Rodríguez, J. M., S. S. Gonzalez, G. D. Mendoza, R. Barcena, M. A. Cobos, A. Hernandez, and M. E. Ortega. 2002. Effect of exogenous fibrolytic enzyme on ruminal fermentation and digestibility of alfalfa and rye-grass hay fed to lambs. J. Anim. Sci. 80:3016-3020. 
Poore, M. H., J. A. Moore, T. P. Eck, R. S. Swingle, and C. B. Theurer. 1993. Effect of fiber source and ruminal starch degradability on site and extent of digestion in dairy cows. J. Dairy Sci. $76: 2244-2253$.

Simas, J. M., J. T. Huber, C. B. Theurer, K. H. Chen, F. A. Santos, and Z. Wu. 1997. Influence of fat source and sorghum grain treatment on performance and digestibilities of high yielding dairy cows. J. Dairy Sci. 80:2907-2912.

Theurer, C. B., J. T. Huber, A. Delgado-Elorduy, and R. Wanderley. 1999. Invited review: Summary of steam-flaking corn or sorghum grain for lactating dairy cows. J. Dairy Sci. 82:1950-1959.

Valadares, R. F. D., G. A. Broderick, S. C. Valadares Filho, and M. K. Clayton. 1999. Effect of replacing alfalfa silage with high moisture corn on ruminal protein synthesis estimated from excretion of total purine derivatives. J. Dairy Sci. 82:2686-2696.

Van Soest, P. J., J. B. Robertson, and B. A. Lewis. 1991. Carbohydrate methodology, metabolism, and nutritional implications in dairy cattle: Methods for dietary fibre, neutral detergent fibre, and nonstarch polysaccharides in relation to animal nutrition. J. Dairy Sci. 74:3583-3597.

Voelker Linton, J. A., and M. S. Allen. 2009. Nutrient demand interacts with forage family to affect nitrogen digestion and utilization responses in dairy cows. J. Dairy Sci. 92:1594-1602.

Wang, B., S. Y. Mao, H. J. Yang, Y. M. Wu, J. K. Wang, S. L. Li, Z. M. Shen, and J. X. Liu. 2014. Effects of alfalfa and cereal straw as a forage source on nutrient digestibility and lactation performance in lactating dairy cows. J. Dairy Sci. 97:7706-7715.

Weiss, W. P., and D. J. Wyatt. 2000. Effect of oil content and kernel processing of corn silage on digestibility and milk production by dairy cows. J. Dairy Sci. 83:351-358

Wilkerson, V. A., B. P. Glenn, and K. R. McLeod. 1997. Energy and nitrogen balance in lactating cows fed diets containing dry or high moisture corn in either rolled or ground form. J. Dairy Sci. 80:2487-2496.

Yu, P., J. T. Huber, F. A. Santos, J. M. Simas, and C. B. Theurer. 1998. Effects of ground, steam-flaked, and steam-rolled corn grains on performance of lactating cows. J. Dairy Sci. 81:777-783.

Zhao, T. Z., and H. Y. Li. 2009. Study on ruminal degradation of mainly protein and fiber sources in dairy diets. Contemp. Anim. Husb. 11:29-32.

Zhong, R. Z., J. G. Li, Y. X. Gao, Z. L. Tan, and G. P. Ren. 2008. Effects of substitution of different levels of steam-flaked corn for finely ground corn on lactation and digestion in early lactation dairy cows. J. Dairy Sci. 91:3931-3937.

Zhu, W. Y. Fu, B. Wang, C. Wang, J. A. Ye, Y. M. Wu, and J. X. Liu. 2013. Effects of dietary forage sources on rumen microbial protein synthesis and milk performance in early lactating dairy cows. J. Dairy Sci. 96:1727-1734. 